\title{
Persistence of Early-Generated Neurons in the Rodent Subplate: Assessment of Cell Death in Neocortex during the Early Postnatal Period
}

\author{
F. Valverde, L. López-Mascaraque, M. Santacana, and J. A. De Carlos \\ Laboratorio de Neuroanatomía Comparada, Instituto Cajal (CSIC), 28002 Madrid, Spain
}

In the rat, the deepest neocortical layer forms a conspicuous cell band known as layer VIb. Cells in layer VIb are among the first to differentiate, and it has been regarded as an homolog to the subplate of primates and carnivores. Cell death has been considered a universal feature of subplate cells. In order to assess the validity of this assertion, we examined the sequence of generation and the extent of cell death in layer VIb. This was achieved using injections of ${ }^{3} \mathrm{H}$-thymidine and two methods for the direct visualization of apoptotlc flgures. Single injections of ${ }^{3} \mathrm{H}$-thymidine were performed between E12 and E15 (E0 is the day of insemination), and brains were examined at different postnatal ages between P1 and P63. The number of heavily labeled cells were counted in layer VIb in six standard, equally spaced coronal sections in each brain. Single injections at E12 labels about $3 \%$ of the entire population of layer VIb cells, $17 \%$ at $E 13,30 \%$ at $E 14$, and $<1 \%$ at $E 15$. Our results indicate that the absolute number of heavily labeled cells in layer VIb remains constant. The analysis of variance (one-way ANOVA) showed that the difference among the group means was not significant from P1 to P63 after injections at either E12, E13, or E14. In order to confirm these results, we evaluated the distribution of pyknotic (apoptotic) cell bodies in the neocortex. Apoptotic cells were visualized in Nissl preparations and by histochemical staining using an in situ apoptosis detection kit. The analysis was performed in rats from E18 to P15. Both methods gave comparable results. We found that the amount of cell death in layer VIb is neither particularly prominent nor significantly different from that which occurs in the remaining neocortical layers, apart from layer II and in the white matter of the corpus callosum. We conclude that neuronal death does not play any significant role in the rodent subplate.

[Key words: development, subplate, cell death, layer VIb, autoradiography, apoptosis]

In rodents, the deepest neocortical layer forms a conspicuous cell band located immediately above the white matter, more com nonly known as layer VIb. Separated from the base of layer

\footnotetext{
Received Dec. 28, 1994; revised Feb. 16, 1995; accepted Feb. 22, 1995

This work was supported by Research Project PB91-0066 from the Ministerio de Educacion y Ciencia (MEC) of Spain. We thank Dr. A. Ruiz-Marcos for statistical consultation.

Correspondence should be addressed to Prof. F. Valverde, Instituto Cajal (CSIC), Avenida del Doctor Arce 37, 28002 Madrid, Spain.

Copyright (C 1995 Society for Neuroscience $0270-6474 / 95 / 155014-11 \$ 05.00 / 0$
}

VI by a cell-sparse band, layer VIb festoons all around the corpus callosum from the level of the claustrum to the cingulum bundle. It is visible even at low magnification, and has been recognized as an independent layer, possibly a rodent specialization (Krieg, 1946; König et al., 1975; Rickmann et al., 1977; Kristt, 1979; Divac et al., 1987b; Reep and Goodwin, 1988; Valverde et al., 1989). Cells in layer VIb are among the first neocortical cells to differentiate (König et al., 1977; Rickmann et al., 1977; Raedler and Raedler, 1978; Raedler et al., 1980; Reep and Goodwin, 1988) and therefore it has been regarded as the homolog of the subplate of primates and carnivores (Valverde et al., 1989; Bayer and Altman, 1990).

Neuronal death has been considered a universal feature for subplate cells. This assumption has becn largcly based on the fact that during the first postnatal weeks, the number of subplate cells decreases (Luskin and Shatz, 1985; Chun and Shatz, 1989) and/or by the disappearance of immunoreactivity to several antigens and specific markers (Chun et al., 1987; Wahle et al., 1987; Wahle and Meyer, 1987, 1989; Allendoerfer et al., 1990; Naegele et al., 1991; Allendoerfer and Shatz, 1994). Degenerating neurons were observed in the subplate of the monkey (Kostovic and Rakic, 1980) and cat (Valverde and Facal-Valverde, 1987, 1988). However, in our subsequent study on the development and differentiation of layer VIb in the rat (Valverde et al., 1989) we did not find an equivalent number of degenerating cells as were found in the cat. We concluded that cells in the rodent layer VIb can be considered equivalent to the subplate cells of primates and carnivores with an important characteristic: their persistence in the adult.

This was in sharp contrast to other studies carried out in rodents in which the population of subplate cells was estimated to decrease considerably after birth (Al-Ghoul and Miller, 1989; Ferrer et al., 1990; Woo et al., 1991; Wood et al., 1992). In view of these contrasting differences, we decided to investigate the persistence of early-generated cells and the presence and extent of cell death in layer VIb of the rat using two different approaches: (1) injections of ${ }^{3} \mathrm{H}$-thymidine in timed pregnant rats during gestation in order to compare the number of heavily labeled cells at early postnatal age with the number found after long survival times, and (2) by direct visualization of apoptotic figures to estimate the amount and localization of cell death during the early postnatal period, a time supposed to correspond with the peak of neuronal cell death. We found that the amount of cell death in layer VIb is neither particularly prominent nor significantly different to that seen in the remaining neocortical layers, apart from layer II and in the white matter. We conclude 


\begin{tabular}{|c|c|c|}
\hline $\begin{array}{l}\text { Age at } \\
\text { injection }\end{array}$ & $\begin{array}{l}\text { Age at } \\
\text { perfusion }\end{array}$ & $N$ \\
\hline \multicolumn{3}{|l|}{ Group 1} \\
\hline E12 & P1 & 3 \\
\hline E12 & P6 & 2 \\
\hline $\mathrm{E} 12$ & P11 & 3 \\
\hline E12 & $\mathrm{P} 21$ & 2 \\
\hline E12 & P63 & 1 \\
\hline \multicolumn{3}{|l|}{ Group 2} \\
\hline E13 & P1 & 3 \\
\hline E13 & P3 & 2 \\
\hline E13 & P6 & 1 \\
\hline E13 & P11 & 1 \\
\hline E13 & $\mathrm{P} 21$ & 1 \\
\hline E13 & P63 & 2 \\
\hline \multicolumn{3}{|l|}{ Group 3} \\
\hline E14 & $\mathrm{P} 1$ & 3 \\
\hline E14 & P5 & 1 \\
\hline E14 & $\mathrm{P} 21$ & 1 \\
\hline E14 & P63 & 1 \\
\hline \multicolumn{3}{|l|}{ Group 4} \\
\hline E15 & P4 & 3 \\
\hline \multirow[t]{2}{*}{ E15 } & P12 & 1 \\
\hline & & 31 \\
\hline
\end{tabular}

that neuronal death does not play any significant role in the rodent subplate.

\section{Materials and Methods}

Animals. Wistar rats raised in the animal colony of the Institute were used in the present study. Postnatal animals were obtained from timed pregnant rats. The day of insemination was defined as embryonic (E) day 0 , and the first $24 \mathrm{hr}$ after birth, as postnatal (P) day 0 . Pups were born on E22 (P0). All animals were handled in an humane manner to avoid major distress, and anesthetized with Equithesin $(3 \mathrm{ml} / \mathrm{kg}$ body weight).

Autoradiography. Pregnant rats of known gestational ages were injected intraperitoneally with $3-7 \mu \mathrm{Ci} / \mathrm{g}$ body weight of ${ }^{3} \mathrm{H}$-thymidine (Amersham, $\left[6-{ }^{3} \mathrm{H}\right]$ thymidine, specific activity $20-30 \mathrm{Ci} / \mathrm{mmol}$ ) and allowed to deliver normally. Offspring and older animals were perfused through the left ventricle with $10 \%$ formaldehyde in phosphate buffer. After perfusion, the brains were embedded in Paraplast and sectioned at 7-8 $\mu \mathrm{m}$ in the frontal plane. Twin serics of equally spaced sections (two adjacent sections out of every 10-15) were mounted on gelatincoated slides, dipped in Kodak NTB-2 or Ilford K5D emulsions, and stored in light-proof boxes at $4^{\circ} \mathrm{C}$ for 6 weeks. The slides were finally developed in D19 developer and stained with thionine before coverslipping. The material available for this study consisted on 31 brains collected in four groups that received injections at E12, E13, E14, and E15 and allowed to survive for different periods, as indicated in Table 1.

Technical considerations. For the evaluation of labeled cells, autoradiographic material was examined in bright and dark field. Labeled cells were assessed for the grain number overlying their nuclei. A cell was considered positive (heavily labeled) when it contained more than one-half the maximum number of silver particles found in the most heavily labeled cell in that particular brain. For instance, in the case of animals injected at E12, it is known that the cells of the accessory olfactory bulb are generated at this age (Bayer, 1983; Valverde and Santacana, 1994) and, consequently, they appeared most intensely labeled (Fig. 1A). In this particular case, the number of silver grains overlying these cells was chosen to serve as reference for the most heavily labeled cells. The evaluation of the number of silver grains (Fig. $1 B$ ) was conducted using image processing software (Global Lab Image
Table 2. Evaluation of apoptotic cell bodies

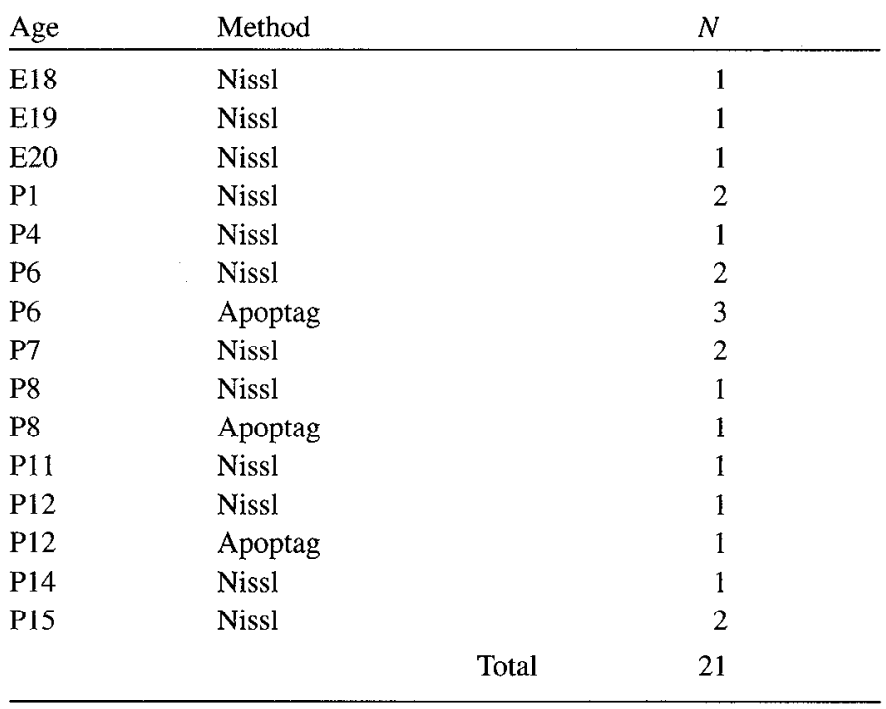

from Data Translation, Marlboro, MA) as detailed elsewhere (Valverde and Santacana, 1994). Although these criteria were not followed in obvious cases of heavy label, they serve to differentiate cells containing less silver grains, especially in animals injected at E12 and E13.

The absolute number of labeled cells was obtained by counting labeled neurons in layer VIb using a $63 \times$ dry objective in six standard frontal sections for each animal (see Results). The brain maps of Swanson (1992) were used as a reference guide for identification of the different structures. The reconstructions of the distribution of labeled cells was obtained with the aid of a computer-based reconstruction program (DESIGNCAD 3-D, American Small Business Computers, Pryor, OK).

Identification of apoptotic cells. Dying cells of the type considered "nuclear" (Pilar and Landmesser, 1976; Cunningham, 1982; Clarke, 1990) are recognized by the condensation of the nucleus into darkly and sometimes fragmented, perfectly spherical masses forming typical apoptotic bodies, which are often surrounded by a thin rim of pale cytoplasm. In this study, apoptotic bodies were visualized in Niss] stained sections and by histochemical staining of the fragmented DNA of dying cells. Neither method allows recognition of the cell type in question but can be useful to evaluate the number and distribution of degenerating cells. For Nissl staining, $40-\mu \mathrm{m}$-thick sections from each animal were chosen that correspond to planes 10,20 , and 30 of the atlas of Swanson (1992)

The biochemical hallmark of apoptosis is a condensation of chromatin with the activation of endonucleases resulting in "laddering" of DNA. This results in the formation of intact cellular fragments termed apoptotic bodies (Gavrieli et al., 1992; Wijsman et al., 1993). The visualization of apoptotic cells by histochemical staining was carried out using an in situ apoptosis detcetion kit (Apoptag peroxidasc kit, Oncor, Gaithersburg, MD). The method is based on the specific binding of terminal deoxynucleotidyl transferase (TdT), an enzyme that catalyzes the addition of digoxigenin polymers at sites of DNA breaks, which appear in high concentration in apoptotic bodies. In brief, $10-\mu \mathrm{m}$-thick paraffin sections were mounted on Vectabond (Vector Labs, Burlingame, CA) precoated slides. After deparaffination and rehydration, sections were treated with the Oncor Protein Digesting Enzyme (Oncor, Gaithersburg, MD). We continued the step-by-step protocol, following the manufacturer's instructions for preparations. Negative controls were performed by substituting the TdT enzyme for distilled water in the preparation of the working strength $\mathrm{TdT}$ reagent.

The ages and methods used for evaluation of apoptotic cell bodies are shown in Table 2. The distribution of apoptotic cells was mapped from representative sections using the same computer-based reconstruction program mentioned previously. Since we are presently interested in correlating the persistence of heavily labeled cells in layer VIb, after ${ }^{3} \mathrm{H}$-thymidine injections with the absence of any significant cell death in this layer, no further attempts were made to look for differences in the distribution of cell death in the cortical layers at distinct pre- and postnatal ages or any variation in the cell death rate. 

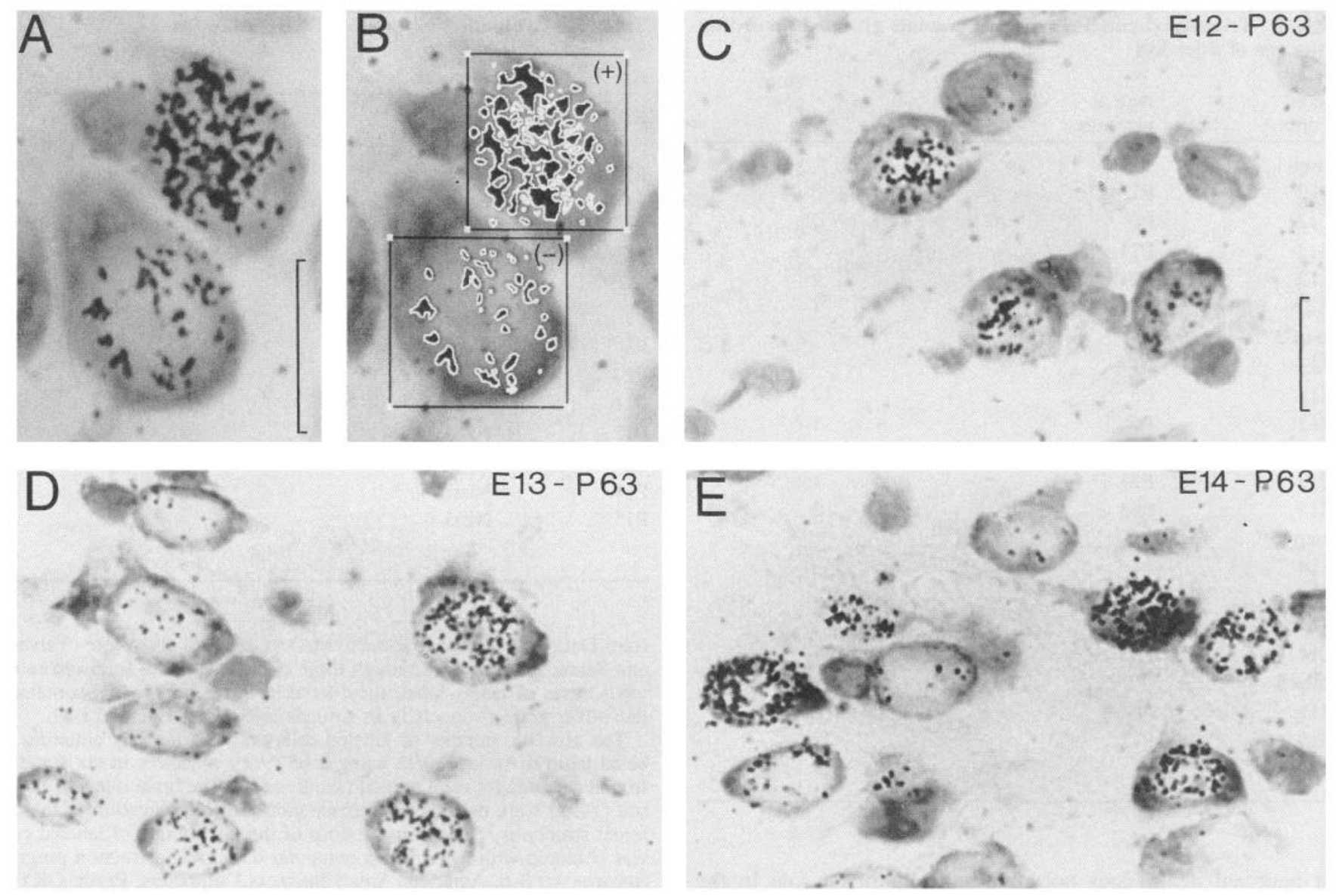

Figure 1. Evaluation of ${ }^{3} \mathrm{H}$-thymidine labeling patterns. A, Video image of two labeled cells in the accessory olfactory bulb at P63 after a single injection of ${ }^{3} \mathrm{H}$-thymidine at E12. B, Video image of the same two cells processed for particle quantification as explained in Material and Methods. The upper cell in $A$ and $B$ was found to contain the largest number of silver grains (68, computer data); therefore, it was considered positive ( + ); the lower cell contains less than one-half of the maximum number of particles (32) and therefore it was considered negative ( - ). $A$ and $B$ serve to illustrate the method used in the evaluation of heavily labeled cells in layer VIb. Heavily labeled cells in layer VIb at P63 following a single injection of ${ }^{3} \mathrm{H}$-thymidine at E12 $(C)$, E13 $(D)$, and E14 $(E)$. Scale bars, $10 \mu \mathrm{m}$.

\section{Results}

The distribution of heavily labeled cells in layer VIb from newborn to adult after ${ }^{3} \mathrm{H}$-thymidine injections

Together with neurons in the marginal zone or layer I, layer VIb contains the first postmitotic neurons produced during development of the rodent neocortex. Injections of ${ }^{3} \mathrm{H}$-thymidine given before the development of the cortical plate consistently label the population of cells corresponding to layer VIb of the adult (Fig. $1 C, D, E$ ). These cells are generated between $\mathrm{E} 12$ and E15, with peak production at E14. The cells of layer VIb reside initially at the base of the cortical plate (Bayer and Altman, 1990; Valverde and Santacana, 1994), but from E17 onwards, they can be recognized as an independent stratum of cells that remains clearly identifiable at all postnatal ages.

Figures 2 and 3 show the distribution of heavily labeled cells in layer VIb at different postnatal ages after ${ }^{3} \mathrm{H}$-thymidine injections at E13. All sections were taken at the same magnification at a level corresponding to plane 20 of the atlas of Swanson (1992) passing through the somatosensory cortex (Fig. 2B). A comparison of these dark-field autoradiographs shows a uniform distribution at P1, P6, and P63 of heavily labeled cells that remain clearly separated from the rest of the cortical layers at all postnatal ages.

Interestingly, discrete clusters of labeled cells were found in the nucleus caudatus (CPU) immediately below the corpus callosum (Fig. 3, arrowheads). Similar groups of cells were also observed after ${ }^{3} \mathrm{H}$-thymidine injections at E12. These early-generated cells probably correspond to striatal "displaced" neurons that have been shown to belong hodologically to layer VIb neurons (Divac et al., 1987a,b). It is possible that some cells on

Figure 2. The distribution of labeled cells at P1 in a transverse section at the level of the somatosensory cortex after a single injection of ${ }^{3} \mathrm{H}-$ thymidine at E13. A, Dark-field mosaic reconstruction of the lateral part of layer VIb $(V I b)$ bordering the corpus callosum $(C C)$. The limits between layer VIb and the remaining cortical layers are marked by arrows. Although increased background is present in this preparation, the majority of heavily labeled cells appear in layer VIb. Inset B shows a reproduction made from plane 20 of the atlas of Swanson (1992) corresponding to the level of the somatosensory cortex in $A$. Layer VIb is marked in solid black. $C A$, commissura anterior; $C C$, corpus callosum; $C G$, cingulum bundle; $C H$, optic chiasm; $C L$, claustrum; $C P U$, nucleus caudatus-putamen; $S R$, sulcus rhinalis. 


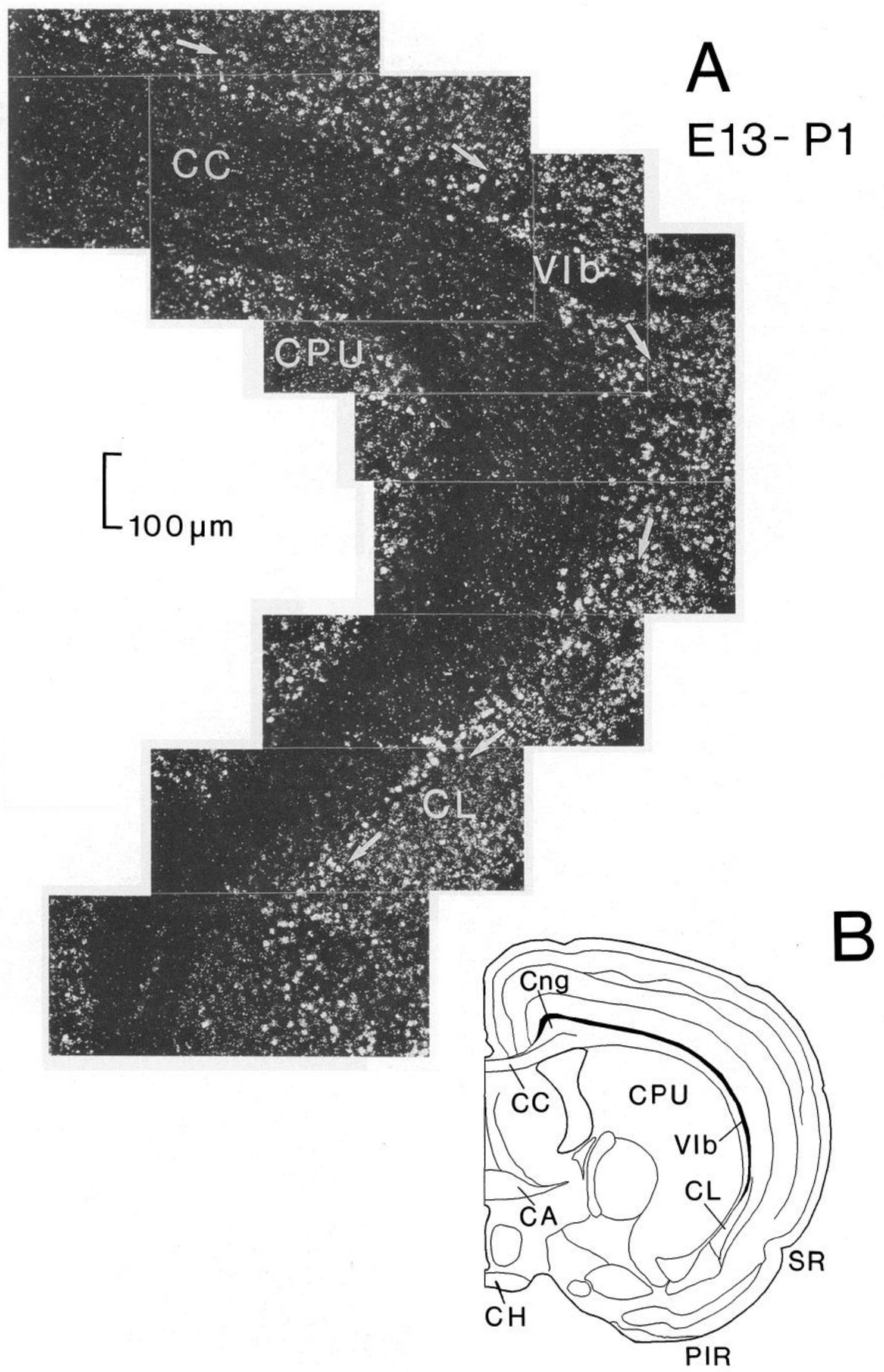




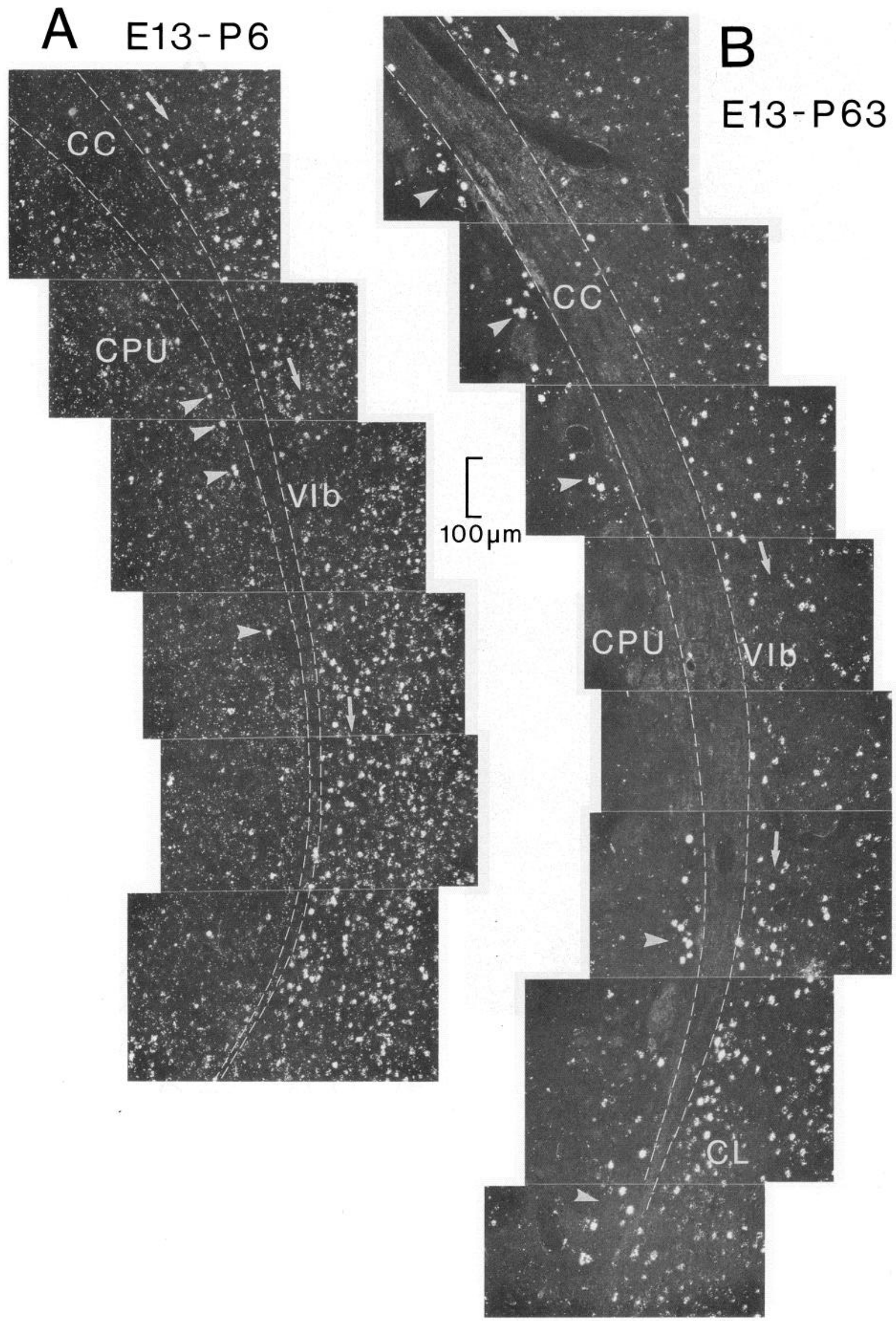




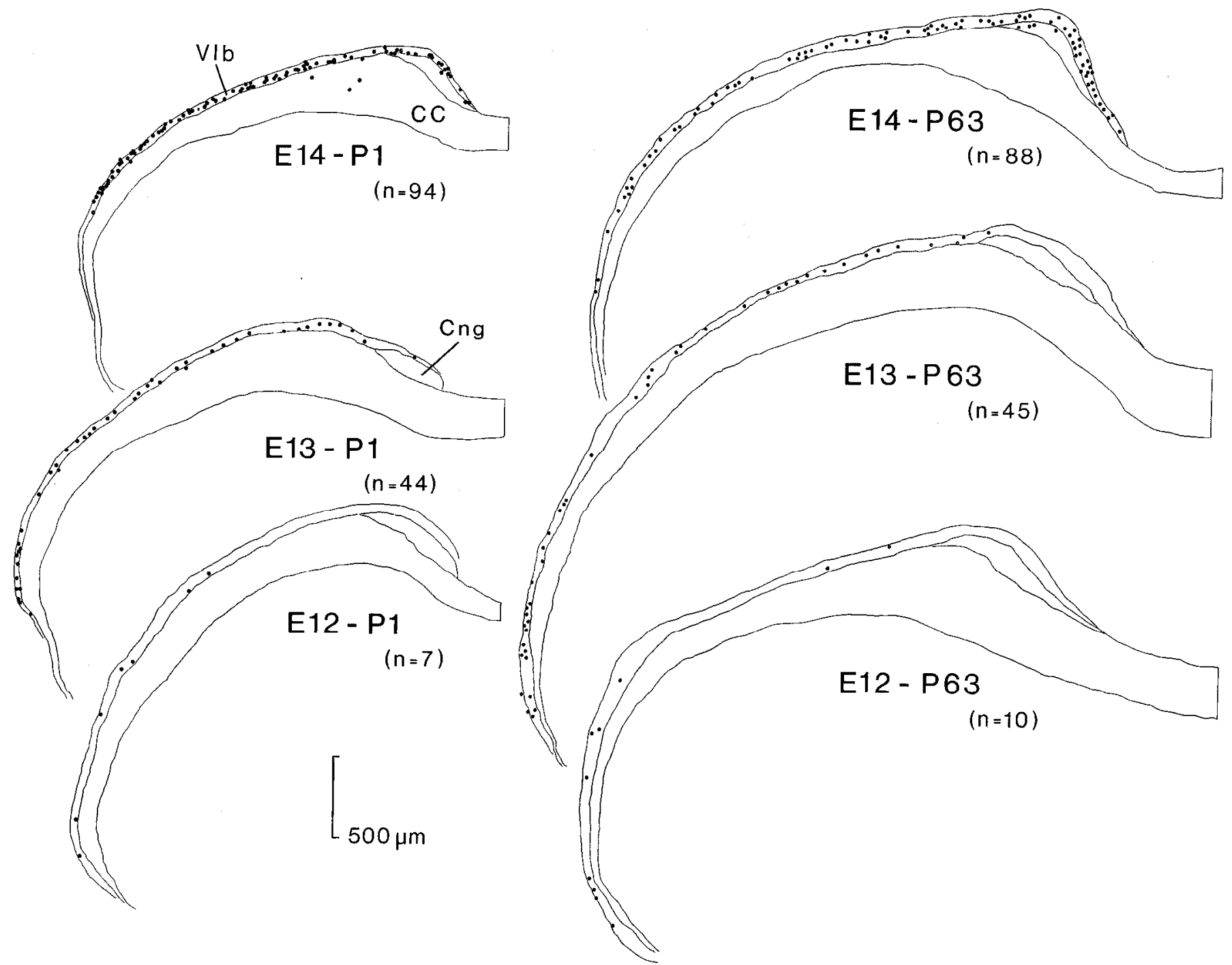

Figure 4. Gradient of generation and distribution of layer VIb cells. Heavily labeled cells in layer VIb at PI after single injections of ${ }^{3} \mathrm{H}$-thymidine at E12, E13, and E14 $(A)$, and at P63 after E12, E13, and E14 injections $(B)$. The comparison by pairs of the distribution of heavily labeled cells between E12, E13, and E14 injected animals at P1 and at P63 shows not only that the total number of heavily cells $(n)$ remains similar, but also that there is a lateromedial gradient of generation; cells born at E12 occupy the lateral region, cells born at E13 extend through the central part, while cells born at E14 are located more medially, close to the cingulum bundle $(C n g)$. $C C$, corpus callosum.

both sides of the corpus callosum exist initially as a single stratum of cells that disperse when separated by the developing corpus callosum.

When the entire population of layer VIb cells is considered as a whole, a spatial gradient of genesis becomes apparent. This is illustrated in Figure 4, in which a comparison has been made between the distribution of heavily labeled cells at P1 (left panel) and at P63 (right panel) after ${ }^{3} \mathrm{H}$-thymidine injections at $\mathrm{E} 12$, E13, and E14. Cells in layer VIb born at E12 appear located in the most ventrolateral aspect, while those generated at E13 and E14 occupy progressively more dorsal regions. The presence of labeled cells embedded in the corpus callosum and cingulum bundle should be mentioned (Fig. 4, E14-P1). In view of their position, these cells may be considered to be equivalent to true interstitial neurons found in carnivores and primates. However, we found that some of these cells are generated over a protracted period, and that some persist in the adult.

The total number of heavily labeled cells remains constant in layer VIb from newborn to adult

Six levels were chosen for evaluation of the total number of heavily labeled cells in layer VIb from P1 to P63. These levels correspond to the frontal planes $10,15,20,25,30$, and 35 of the atlas of Swanson (1992). The planes are separated by about

$\leftarrow$

Figure 3. The distribution of labeled cells at P6 $(A)$ and P63 $(B)$ after single injections of ${ }^{3}$ H-thynindine at E13. Transverse sections passing through the lateral part of layer VIb at the level of the somatosensory cortex (for reference, see Fig. $2 B$ ). Dark-field mosaic reconstructions. The profile of the corpus callosum $(C C)$ is outlined by dashed lines. The external limits of layer VIb (VIb) follow the path marked by arrows. There is increased background in young animals $(A)$, but the majority of heavily labeled cells concentrate in layer VIb. Note clusters of heavily labeled cells in the external part of the nucleus caudatus putamen $(C P U)$ flanking the corpus callosum $(C C)$. $C L$, claustrum. 


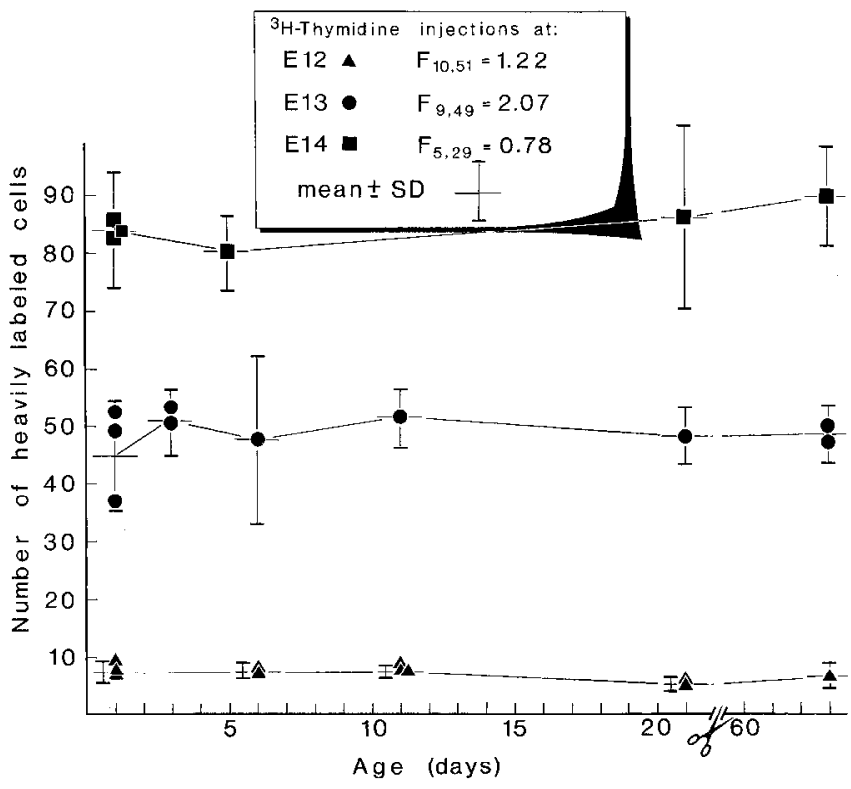

Figure 5. Number of heavily labeled cells after ${ }^{3} \mathrm{H}$-thymidine single injections at E12, E13, and E14 at different postnatal ages. Each plot represents the mean value obtained from six equally spaced standard sections (see Results) in each animal. The values for $F$ correspond to the results of the analysis of variance. The two subscripts indicate the degrees of freedom of the numerator and denominator of $F$. The analysis of variance (one-way ANOVA) show that the variability between animal mean values was found not to be significantly different that the residual variability within the groups. Thus, the data provide no evidence that the mean values differ from one another at all postnatal ages.

$1 \mathrm{~mm}$, extending from the motor area $(2.5 \mathrm{~mm}$ from the rostral pole of the brain hemisphere) to the caudal border of the corpus callosum at the level of the primary visual cortex. The number of heavily labeled cells (as defined in Material and Methods) were counted in layer VIb, extending from the cingulum bundle to the claustrum (layer VIb appears drawn in black in Fig. $2 B$ ). The counts were done in the six selected sections for each brain, and the mean values for each animal were obtained. In several cases, counts were performed in both hemispheres, and the mean value for that plane was obtained. However, in most cases no great differences were found between either side.

Except for the first section corresponding to plane 10 of Swanson (1992), in which the length of layer VIb is substantially shorter (about $3 \mathrm{~mm}$ ), the length (measured with a curvimeter in camera lucida drawings) in the remaining planes do not vary significantly from each other (layer VIb is about $5 \mathrm{~mm}$ in length in the remaining planes). There were also no significant differences in the total number of heavily labeled cells in the different sections in the same animal. Hence, the values from each of the planes were pooled to calculate the mean value for each animal. The data of this analysis is presented in the graph of Figure 5. The mean value of heavily labeled cells for each animal, after ${ }^{3} \mathrm{H}$-thymidine injections at E12, E13, and E14, were plotted at the different ages studied. The analysis of variance (one-way ANOVA) showed that the difference among the group means was not significant and thus the present data provides no evidence that each group differ from one another.

Combining the mean values of heavily labeled cells versus the total number of cells in layer VIb per section (about 280, see below), the percentage of heavily labeled cells in layer VIb after a single ${ }^{3} \mathrm{H}$-thymidine injection were as follows: at E12
(3\%), at E13 (17\%), and at E14 (30\%). Counts obtained at P4 and P12 (see Table 1), after single ${ }^{3} \mathrm{H}$-thymidine injections at E15, revealed that only a small percentage $(<1 \%)$ of cells in layer VIb were heavily labeled.

The total number of cells per section (labeled and unlabeled cells with visible nuclei in 7-8 $\mu \mathrm{m}$ paraffin sections) in layer VIb was determined by the analysis of five brains: two at P1, one at P6, and two at P63. The number of cells were counted in the six reference planes for each animal. Although one would expect some dilution and fewer cells per section as the brain is growing in size, differences were not highly significant. For instance, the mean value for P6 in one case was 286.6 cells per section, with a standard deviation of \pm 43.7 ; the mean value for P63 in another case was 268.8 cells per section with a standard deviation of $\pm 29.5(d f=5 ; t=0.63)$.

\section{Apoptosis}

The distribution of dying cells (apoptotic figures) was found to be similar in Nissl-stained sections and sections treated with the ApopTag kit. Apoptotic figures in Nissl material were recognized by the presence of darkly stained, sometimes fragmented, round masses surrounded by a pale halo (Fig. 6A). In sections reacted with the ApopTag kit, apoptotic cells show intense dark brown staining in nuclei and nuclear fragments against a light brown staining of nonapoptotic nuclei (Fig. 6B,C,D). No staining of the cytoplasm was observed.

Plane 20 of the atlas of Swanson (1992), passing through the central part of the somatosensory area, was chosen to represent the distribution of dying cells from a Nissl-stained preparation (Fig. 7A), and after treatment with the ApopTag kit (Fig. 7B) at P6, a time supposed to be at the peak of neuronal death in the rodent brain (Ferrer et al., 1990; Woo et al., 1991). Apoptotic figures were distributed in three levels: in the ependymal layer lining the lateral ventricle (Fig. 7, EL), in the corpus callosum (CC), and in layer II (II). In the rest of the neocortex, including laycr VIb, apoptotic bodies were distributed randomly without any significant difference for any given layer, except layer II. This distribution of apoptotic bodies remained relatively constant from P1 to P8. Apoptotic bodies were first recognized at $\mathrm{P} 1$; their number increased during the first postnatal week, reaching a maximum level around P6-P8 and declined after that. Taken together, these data confirm the absence of any significant cell luss in layer VIb at the ages we have studied.

\section{Discussion}

The term subplate layer coined by Kostovic and Molliver (1974) designates a prominent, albeit transient stratum of cells located in the upper part of the intermediate zone of the human brain, during early phases of cortical development (nomenclature of the Boulder Committee, 1970).

In primates (man, monkey), birth-dating studies using ${ }^{3} \mathrm{H}$-thymidine autoradiography provided evidence that interstitial cells of the white matter are among the first-generated neurons of the telencephalon and therefore were considered to represent in the adult, the vestige of the transient subplate layer (Kostovic and Rakic, 1980, 1990). A decrease in the number of subplate neurons during postnatal development and the presence of degenerating "dark" cells, led Kostovic and Rakic (1980) to suggest that cell death may be responsible for this phenomenon.

Similar conclusions were obtained from studies carried out in Carnivores (I uskin and Shat7, 1985; Chun and Shatz, 1989). Injections of tritiated thymidine prior to the genesis of the dif- 

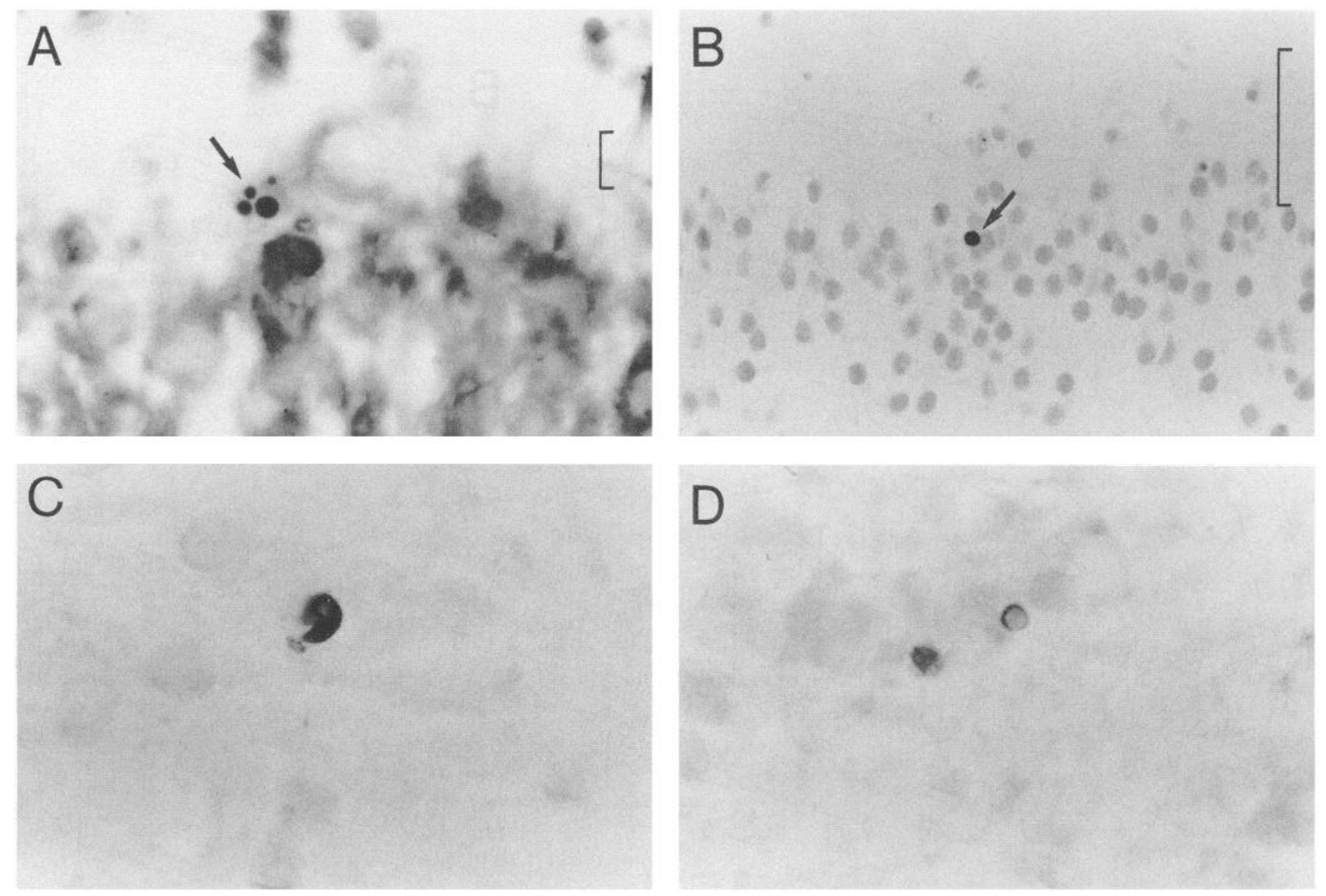

Figure 6. Photomicrographs of pyknotic (apoptotic) cells at P6. A, Apoptotic bodies (arrow) in the upper part of layer II in the somatosensory cortex in Nissl-stained, $40-\mu \mathrm{m}$-thick, transverse section. $B$, One apoptotic cell in layer II (arrow) at the level of the somatosensory cortex. $C$, Apoptotic cell in layer VIb. $D$, Two apoptotic cells in the white matter of the corpus callosum at the level of the sulcus rhinalis. $B-D$ correspond to $6-\mu \mathrm{m}$-thick transverse sections stained with the ApopTag kit. Scale bars: $A, 10 \mu \mathrm{m}$ for $A, C$, and $D ; B, 50 \mu \mathrm{m}$.

ferent cortical layers in the cat label a number of cells in the marginal zone (the first cortical layer or future layer I), and the subplate region (corresponding to the white matter of the adult) at later embryonic ages (Luskin and Shatz, 1985). In this study, both types of cells were rarely preserved in the adult, suggesting that most of them have disappeared by cell death.

In our studies of interstitial (subplate) cells in the temporal cortex of kittens (Valverde and Facal-Valverde, 1987, 1988), we described neuronal cell death in electron microscope images as previously recognized (Pilar and Landmesser, 1976; Chu-Wang and Oppenheim, 1978; Cunningham, 1982; Clarke and Hornung, 1989; Clarke, 1990; Johnson and Deckwerth, 1993). From these studies a generalization emerged: neuronal death was considered a universal feature for subplate cells (see review in Allendoerfer and Shatz, 1994).

In contrast, in our subsequent study in the rat (Valverde et al., 1989), equivalent numbers of degenerating cells to those seen in the cat were not found, suggesting that neuronal death may not be particularly significant in the rodent subplate or layer VIb. The present study confirms this assumption, showing that no significant cell loss is observed from newborn to late postnatal life in layer VIb of the rat.

Here we have shown using ${ }^{3} \mathrm{H}$-thymidine injections that the majority of neurons generated between E12 and E14 come to reside in layer VIb (subplate). We also provide evidence that the number of early-generated cells of layer VIb from newborn rats to 2-month-old rats do not vary significantly. In order to confirm these results, we looked for dying (pyknotic) cells in Nisslstained preparations and using the ApopTag detection kit to label apoptotic bodies. Again, our results did not provide evidence for any significant cell loss in layer VIb.

Although analysis of apoptotic figures does not allow the cell types to be identified, it allowed us to determine if the number of apoptotic cells in layer VIb at any of the embryonic or early postnatal ages studied differs from that seen in other layers. This was not the case, as the number of apoptotic cells in layer VIb does not significantly vary from that found in the remaining cortical layers, except layer II. The criteria that we have used for identification of apoptotic cell death corresponds to wellknown features of apoptosis (Cunningham, 1982; Clarke, 1990; Johnson and Deckwerth, 1993). Nissl- and ApopTag-stained sections gave comparable results. Moreover, as shown by Rabacchi et al. (1994), the same cells revealing DNA fragmentation also appear pyknotic in cresyl violet-stained sections. However, we found apoptotic bodies to be more numerous in Nissl-stained preparations. This difference may be explained by a temporal divergence of pyknosis and DNA fragmentation (Rabacchi et al., 1994) so that some apoptotic bodies detected in Nissl-stained preparations may not be visualized using the ApopTag kit. Moreover, both markers are evident for only a short time in the death 

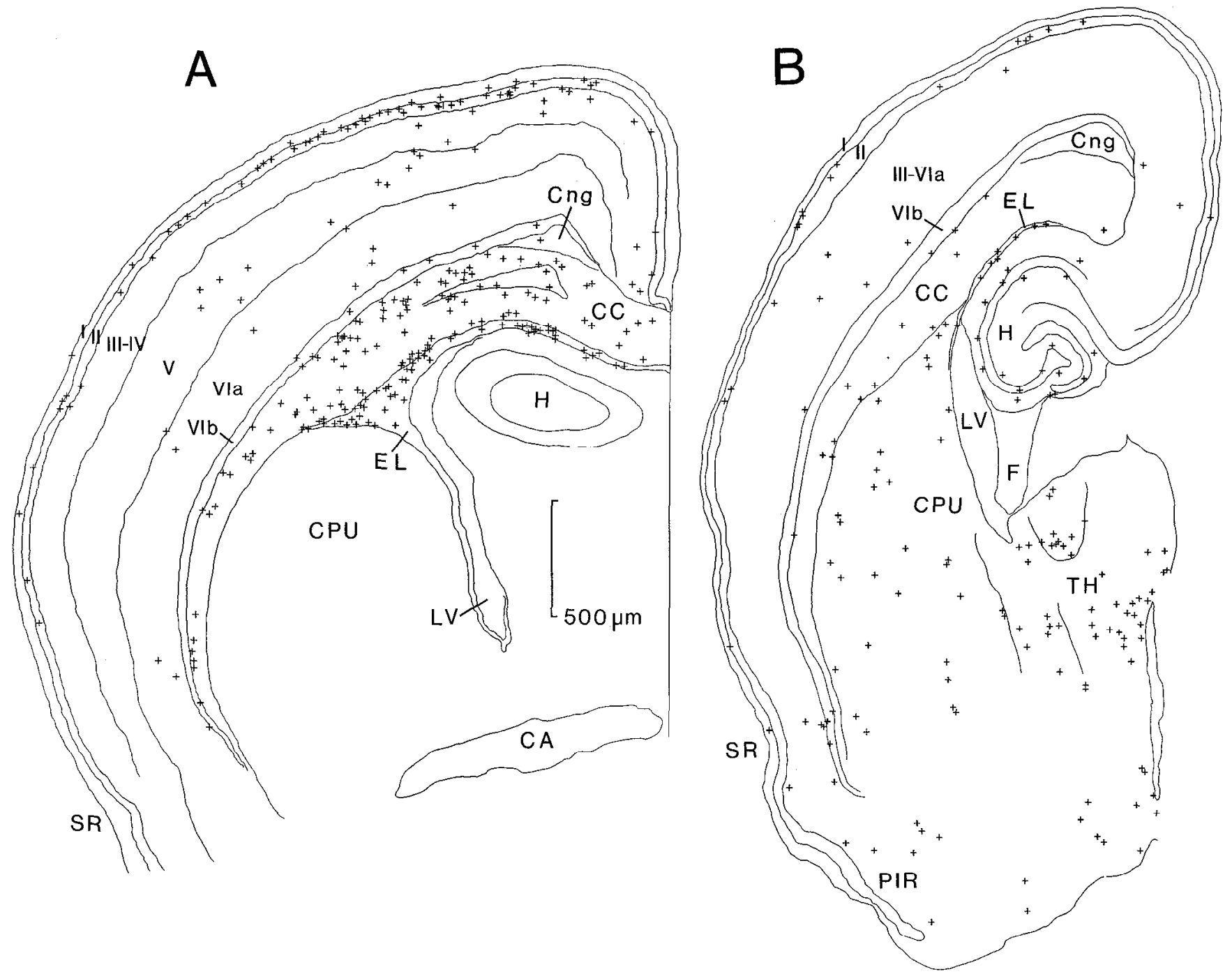

Figure 7. Computer printout of the distribution of pyknotic (apoptotic) cells in transverse sections at the level of the somatosensory cortex at P6. $A$, Nissl-stained $40-\mu \mathrm{m}$-thick section. $B$, ApopTag-reacted 8- $\mu \mathrm{m}$-thick section. In $A$, apoptotic cell bodies were plotted in the neocortex from the midline (right) to the level of the sulcus rhinalis $(S R)$; in the white matter $(C C)$, and in the ependymal layer $(E L)$ lining the lateral ventricle $(L V)$. In $B$, all apoptotic cells contained in this section were plotted. There are fewer apoptotic bodies in the neocortex in sections treated with the ApopTag kit $(B)$. This is a result not only of the distinct section thickness but also on the observation that apoptotic figures appear more readily visualized in Nissl-stained preparations (see Results). In spite of this, the distribution appears coincident in layer II, white matter, and ependymal layer. Each cross represents one apoptotic figure. $C A$, commissura anterior; $C C$, corpus callosum; $C n g$, cingulum bundle; $C P U$, nucleus caudatusputamen; $E L$, ependymal layer; $H$, hippocampus; $L V$, lateral ventricle, $S R$, sulcus rhinalis; $I-V I b$, neocortical layers.

of a given cell, so that it is possible that more cells are dying than are displayed by these methods.

The present observations are in contrast to previous studies carried out in several rodents in which massive neuronal death has been reported in layer VIb. Al-Ghoul and Miller (1989) injected ${ }^{3} \mathrm{H}$-thymidine at $\mathrm{E} 12$ in the rat and found labeled neurons in the subplate (layer VIb) on P8, but by P20 no labeled neurons were observed. The contrast between this data and our own may be explained by the low proportion of cells generated at E12 in layer VIb (3\% after single injections, present results and Bayer and Altman, 1990). This small population may be difficult to localize in a single section of a large brain unless several adjacent sections, as in the present study, were analyzed. In the same study, Al-Ghoul and Miller (1989) included labeling experiments using the monoclonal antibody Alz-50 (Wolozin el al., 1986). They found that Alz-50 immunoreactivity was tran- siently present in the subplate, disappearing after P5, supporting a relationship between the expression of this antigen and neuronal death. We have previously shown in kittens that Alz-50 does not identify specific populations of neurons, and although Alz-50 immunoreactivity relates to specific developmental changes, it is not particularly associated with the occurrence of neuronal death (Valverde et al., 1990; De Carlos et al., 1991; Liu et al., 1994; Miller at al., 1994).

Wood et al. (1992) have used bromodeoxyuridine to label the earliest-generated cells in the cerebral cortex of the mouse. After injections on E12 or E13, heavily labeled cells were found at E17 or E20 in the deep part of the cortical plate and below it. However, by $\mathrm{P} 21$, few heavily labelled cells were present and they were restricted to the deep cortical layers. From these observations they estimated that a 75 -fold decrease of subplate cells occurred between E17-E20 and P21 in mice. They con- 
cluded that a large part of early-generated cells were eliminated by cell death. Again, these results are difficult to reconcile with our present observations. Layer VIb in the mouse does not appear to be as clearly separated from the remaining cortical layers as in the rat. Therefore, the most likely interpretation is that the E12-E13-generated cells in the study of Wood et al. (1992), which occupied a zone below the cortical plate, come to reside in a deep cortical position homologous to layer VIb in the rat. In the rat, cells destined to form layer VIb reside initially at the base of the cortical plate before settling permanently (by E17) in a separate stratum or layer VIb (Bayer and Altman, 1990, and unpublished observations). In mice, such segregation apparently does not occur and the homolog $10 \mathrm{VIb}$ may correspond to the bottom of layer VI, where many labeled cells were found (see Wood et al., 1992, their Fig. 1D).

In their study in the hamster, Finlay and Slattery (1983) found that degeneration in layers V and VI were small or absent, and no mention was made of layer VIb. However, in a recent publication, Woo et al. (1991), using ${ }^{3} \mathrm{H}$-thymidine injections in the hamster, performed at the time of generation of the subplate and layer VI, showed that the ratio of labeling between layer VIb and layer VI decreased between P4 to adulthood. The rate of cell loss in layer VIb was estimated to amount as much as 50 to $80 \%$. This is also a surprising finding because it means that approximately three to four out of every five cells in layer $\mathrm{VIb}$ die. However, no substantial reduction of the population of cells in this layer could be observed.

Our observations concerning the time schedule and distribution of apoptotic (pyknotic) cell bodies are in agreement with the distribution of dead cells found by Yamamoto et al. (1986) and Ferrer et al. (1990) in the somatosensory cortex of the rat. Cell death was found in greater numbers in the upper cortical layers, mainly in layer II, and in the white matter and corpus callosum. However, the underlying subcortical white matter, in which Ferrer et al. (1990) plotted the largest numbers of dead cells, is erroneously considered as the subplate or layer VIb. We have found large numbers of pyknotic cells in the white matter but we were unable to identify their cell type. It is possible that most of these pyknotic cells represent glial cell degeneration (Soriano et al., 1993), or they may be equivalent to the population of interstitial cells found in larger brains, which have a transitory nature and correspond in part to the population of migratory neurons of the intermediate zone (DeDiego et al., 1994).

In conclusion, our data show that cell death does not play a significant role in the development of the rodent subplate (layer VIb). We consider that this early-generated layer persists from its formation in the embryo to adulthood, and that it may be functionally different from the subplate layer in other species.

\section{References}

Al-Ghoul WM, Miller MW (1989) Transient expression of Alz-50 immunoreactivity in developing rat neocortex: a marker for naturally occurring neuronal death? Brain Res 481:361-367.

Allendoerfer KL, Shatz CJ (1994) The subplate, a transient neocortical structure: its role in the development of connections between thalamus and cortex. Annu Rev Neurosci 17:185-218.

Allendoerfer KL, Shelton DL, Shooter EM, Shatz CJ (1990) Nerve growth factor receptor immunoreactivity is transiently associated with the subplate neurons of the mammalian telencephalon. Proc Natl Acad Sci USA 87:187-190.

Bayer SA (1983) ${ }^{3} \mathrm{H}$-Thymidine-radiographic studies of neurogenesis in the rat olfactory bulb. Exp Brain Res 50:329-340.
Bayer SA, Altman J (1990) Development of layer I and the subplate in the rat neocortex. Exp Neurol 107:48-62.

Boulder Committee (1970) Embryonic vertebrate nervous system: revised terminology. Anat Rec 166:257-262.

Chun JJM, Shatz CJ (1989) Interstitial cells of the adult neocortical white matter are the remnant of the early generated subplate neuron population. J Comp Neurol 282:555-569.

Chun JJM, Nakamura MJ, Shatz CJ (1987) Transient cells of the developing mammalian telencephalon are peptide-immunoreactive neurons. Nature 325:617-620.

Chu-Wang I-W, Oppenheim RW (1978) Cell death of motoneurons in the chick embryo spinal cord. I. A light and electron microscopic study of naturally occurring and induced cell loss during development. J Comp Neurol 177:33-58.

Clarke PGH (1990) Developmental cell death: morphological diversity and multiple mechanisms. Anat Embryol (Berl) 181:195-213.

Clarke PGH, Hornung JP (1989) Changes in the nuclei of dying neurons as studied with thymidine autoradiography. J Comp Neurol 283: $438-449$.

Cunningham TJ (1982) Naturally occurring neuron death and its regulation by developing neural pathways. Int Rev Cytol 74:163-186.

De Carlos JA, López-Mascaraque L, Valverde F (1991) Morphological characterization of Alz-50 immunoreactive cells in the developing neocortex of kittens. In: NATO series A: life sciences, The neocortex: ontogeny and phylogeny (Finlay BL, Innocenti G, Scheich $\mathrm{H}$, eds), pp 193-197. New York: Plenum.

DeDiego I, Smith-Fernández A, Fairén A (1994) Cortical cells that migrate beyond area boundaries: characterization of an early neuronal population in the lower intermediate zone of prenatal rats. Eur J Neurosei 6:983-997.

Divac I, Mogensen J, Marinkovic S, Martensson R (1987a) On the projections from the neostriatum to the cerebral cortex: the "displaced" neurons. Neuroscience 21:197-205.

Divac I, Marinkovic S, Mogensen J, Schwerdtfeger W, Regidor J (1987b) Vertical ascending connections in the isocortex. Anat Embryol (Berl) 175:443-455.

Ferrer I, Bernet E, Soriano E, Del Rio T, Fonseca M (1990) Naturally occurring cell death in the cerebral cortex of the rat and removal of dead cells by transitory phagocytes. Neuroscience 39:451-458.

Finlay BL, Slattery M (1983) Local differences in the amount of early cell death in neocortex predict adult local specializations. Science 219:1349-1351.

Gavrieli Y, Sherman Y, Ben-Sasson A (1992) Identification of programmed cell death in situ via specific labeling of nuclear DNA fragmentation. J Cell Biol 119:493-501.

Johnson EM, Deckwerth TL (1993) Molecular mechanisms of developmental neuronal death. Annu Rey Neurosci 16:31-46.

König N, Roch G, Marty R (1975) The onset of synaptogenesis in the rat temporal cortex. Anat Embryol (Berl) 148:73-87.

König N, Valat J, Fulcrand J, Marty R (1977) The time of origin of Cajal-Retzius cells in the rat temporal cortex. An autoradiographic study. Neurosci Lett 4:21-26.

Kostovic I, Molliver ME (1974) A new interpretation of the laminar development of cerebral cortex: synaptogenesis in different layers of neopallium in the human fetus. Anat Rec 178:395.

Kostovic I, Rakic P (1980) Cytology and time of origin of interstitial neurons in the white matter in infant and adult human and monkey telencephalon. J Neurocytol 9:219-242.

Kostovic I, Rakic P (1990) Develnpmental history of the transient subplate zone in the visual and somatosensory cortex of the macaque monkey and human brain. J Comp Neurol 297:441-470.

Kricg WJS (1946) Conncetions of the cerebral cortex. I. The albino rat. B. Structure of the cortical areas. J Comp Neurol 84:277-323.

Kristt DA (1979) Acetylcholinesterase-containing neurons of layer VIb in immature neocortex: possible component of an early formed intrinsic cortical circuit. Anat Embryol (Berl) 157:217-226.

Liu Y, Dyck R, Cynader M (1994) The correlation between cortical neuron maturation and neurofilament phosphorylation: a developmental study of phosphorylated $200 \mathrm{kDa}$ neurofilament protein in cat visual cortex. Dev Brain Res 81:151-161.

Luskin MB, Shatz CJ (1985) Studies of the earliest generated cells of the cat's visual cortex: cogeneration of subplate and marginal zones. J Neurosci 5:1062-1075.

Miller MW, Murtaugh M, Kuhn PE (1994) Developmental expression 
of a $56 \mathrm{kDa}$ protein isolated from rat neocortex. Dev Brain Res 81: 260-268.

Naegele JR, Barnstable CJ, Wahle PR (1991) Expression of a unique $56-\mathrm{kDa}$ polypeptide by neurons in the subplate zone of the developing cerebral cortex. Proc Natl Acad Sci USA 88:330-334.

Pilar G, Landmesser L (1976) Ultrastructural differences during embryonic cell death in normal and peripherally deprived ciliary ganglia. J Cell Biol 68:339-356.

Rabacchi SA, Bonfanti L, Liu X-H, Maffei L (1994) Apoptotic cell death induced by optic nerve lesion in the neonatal rat. J Neurosci 14:5292-5301.

Raedler E, Raedler A (1978) Autoradiographic study of early neurogenesis in rat neocortcx. Anat Embryol (Berl) 154:267-284.

Raedler E, Raedler A, Feldhaus S (1980) Dynamical aspects of neocortical histogenesis in the rat. Anat Embryol (Berl) 158:253-269.

Reep RL, Goodwin GS (1988) Layer VII of rodent cerebral cortex. Neurosei Lett 90:15-20.

Rickmann M, Chronwall BM, Wolff JR (1977) On the development of non-pyramidal neurons and axons outside the cortical plate: the early marginal zone as a pallial anlage. Anat Embryol (Berl) 151:285-307.

Soriano E, Del Rio JA. Auladell C (1993) Characterization of the phenotype and birthdates of pyknotic dead cells in the nervous system by a combination of DNA staining and immunohistochemistry for 5'-bromodeoxyuridine and neural antigens. J Histochem Cytochem 41:819-827.

Swanson LW (1992) Brain maps: structure of the rat brain. Amsterdam: Elsevier.

Valverde F, Facal-Valverde MV (1987) Transitory population of cells in the temporal cortex of kittens. Dev Brain Res 32:283-288.

Valverde F, Facal-Valverde MV (1988) Postnatal development of interstitial (subplate) cells in the white matter of the temporal cortex of kittens: a correlated Golgi and electron microscopic study. J Comp Neurol 269:168-192.
Valverde F, Santacana M (1994) Development and early postnatal maturation of the primary olfactory cortex. Dev Brain Res 80:96-114.

Valverde F, Facal-Valverde MV, Santacana M, Heredia M (1989) Development and differentiation of early generated cells of sublayer VIb in the somatosensory cortex of the rat: a correlated Golgi and autoradiographic study. J Comp Neurol 290:118-140.

Valverde F, López-Mascaraque L, De Carlos JA (1990) Distribution and morphology of Alz-50-immunoreactive cells in the developing visual cortex of kittens. J Neurocytol 19:662-671.

Wahle P, Meyer G (1987) Morpholngy and quantitative changes of transient NPY-ir neuronal populations during early postnatal development of the cat visual cortex. J Comp Neurol 261:165-192.

Wahle P, Meyer G (1989) Early postnatal development of vasoactive intestinal polypeptide- and peptide histidine isoleucine-immunoreactive structures in the cat visual cortex. J Comp Neurol 282:215-248.

Wahle P, Meyer G, Yu J-Y, Albus K (1987) Morphology and axon terminal pattern of glutamate decarboxylase-immunoreactive cell types in the white matter of the cat occipital cortex during early postnatal development. Dev Brain Res 36:53-61.

Wijsman JH, Jonker RR, Keijzer R, Van De Velde CJH, Cornelisse CJ, Van Dierendonck JH (1993) A new method to detect apoptosis in paraffin sections: in situ end-labeling of fragmented DNA. J Histochem Cytochem 41:7-12.

Wolozin BL, Pruchnicki A, Dickson DW, Davies P (1986) A neuronal antigen in the brains of Alzheimer patients. Science 232:648-650.

Woo TU, Beale JM, Finlay BL (1991) Dual fate of subplate neurons in a rodent. Cercb Cortex 1:433-443.

Wood JG, Martin S, Price DJ (1992) Evidence that the earliest generated cells of the murine cerebral cortex form a transient population in the subplate and marginal zone. Dev Brain Res 66:137-140.

Yamamoto T, Iwasaki Y, Konno H, Iizuka H (1986) Identification of cells undergoing physiological neuronal death in the neonatal rat brain by the Fink-Heimer method. Brain Res 374:419-424. 